解 説

\title{
フラクタル次元と粉体工学への応用
}

Fractal Dimension and its Application for Powder Technology

\author{
鈴 木 道 隆* \\ Michitaka SUZUKI
}

Key Words : Fractal Dimension, Powder Technology, Particle Shape, Packing Structure

1. はじめに

最近, 工学, 理学, 医学などのいろいろな分野でフ ラクタルとかフラクタル次元とかいう言葉を目にする てとが多くなってきている。てのフラクタル次元は, 本解説の引用文献が 1980年以降のあのしかないてとか らあ分かるように，たいへん新しい概念である。その ためか, このフラクタル次元とは何を意味し, どのよ うにして測定し, さらに粉体工学にどのように応用で きるのかについての分かりやすい解説はあまり見あた らない。

以前, 粉体工学会誌の「新しい言葉, 古い言葉」に フラクタル関係の言葉の説明をいくつか書いたのがき っかけで, このような解説を書く機会に恵まれたので, 私なりにフラクタル次元の概念と粉体工学への応用に ついてまとめてみた。あちろん充分なあのではないが, ての解説が皆様にとってなんらかのお役に立てば幸い である。

2. 次元とは何か

まず, 1, 2, 3 次元のように，てれまで一般的に広く 用いられている次元は, どのようにして求められるの かを考えてみよう。一般に点は 0 次元, 直線や線分は

平成 2 年 5 月 15 日受付

* 姫路工業大学工学部産業機械工学教室

(干 671-22 姫路市春写 2167)

TEL 0792-66-1661 内線 249
1 次元, 正方形や長方形は 2 次元, 立方体や直方体は 3 次元と言われている。乙れはそれぞれの自由度の数 が直線は長さだけだから 1 つ, 平面は綎之横の 2 つ, 立体は縦, 横, 高さの 3 つであるためと考えられ, こ の定義で別に問題は生じなかった。とてろが 1890年に 数学者のPeanoが, 図1に示すようなPeano曲線と呼 ばれる不思議な一筆書きの折れ線を考えた。乙の図形 は単位図形の数を增やせば正方形内のすべての点をあれ なく通るので平面とも考えられるが，それ自身は 1 本 の折れ線にすぎない。乙のPeano曲線の次元は 1 本の 折れ線だから 1 なのか, それとも単位図形の数を増や してゆけば正方形全体をあれなく通るのだから平面の 2 なのかが数学上の問題となった ${ }^{1) 。}$

Hausdorff とBesicovitchは 1937 年に, 自由度の数 から離れ, 対象の図形を構成する単位図形の個数と単 位長さの逆数の $D$ 乗との間に比例関係が成り立てば,

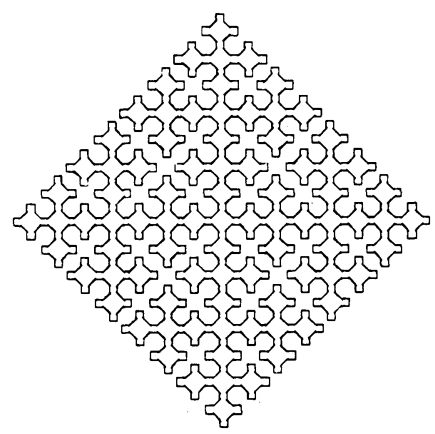

図 1 Peano曲線 
その指数 Dがその図形の次元であるという新しい次元 の定義を考案した。そこでての定義による次元をハウ スドルフ次元あるいは八ウスドルフ・ベシコビッチ次 元之呼ぶ1)。乙の新しい次元の定義は次のようなあの である。

簡単な例として, 図 2 のように直線, 正方形, 立方 体を 2 等分する場合を考える。すると等分して得られ た図形の大きさは元の図形の 2 分の 1 であるが, 形は まったく同じで元の図形の小型模型となっている。乙 のような全体と部分が相似であるという性質を自己相 似性と呼ぶ。これらの図形を 2 等分したときの単位図 形の数は, 図 2 から分かるように直線では 2 , 正方形 では 4 , 立方体では 8 となる。単位図形の個数 $N$ と単 位長さ $r$ との一般的関係を求めるとそれぞれ次の式 (1)，(2)，(3)のようになる。

a）直線の場合には

$$
N=(1 / r)^{1}
$$

b) 正方形の場合には

$$
N=(1 / r)^{2}
$$

c) 立方体の場合には

$$
N=(1 / r)^{3}
$$

これらの式の指数を見ると, 直線で 1 , 正方形 2 , 立 方体で 3 となり，一般的に知られている整数值の次元 と一致する。さて，ての定義に基づいて図 1 の Peano 曲線の次元を求めると, 単位長さを半分にすれば単位 図形の数は 2 倍になるので 2 次元であることが分かる。

図 3 にKoch曲線と呼ばれる特殊な図形を示す。乙 れは直線を 3 等分し，その中央部分を消して長さが初 めの $1 / 3$ の直線を 2 本書き込む操作を無限に繰り返し

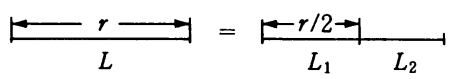

$1 / 2$ の直線を $2^{1}$ 個合わせると元の直線

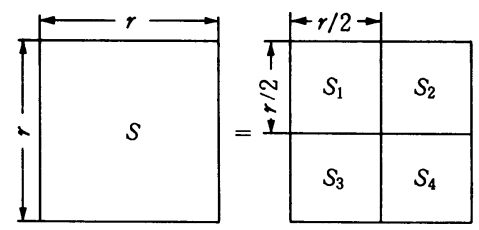

$1 / 2$ の正方形を $2^{2}$ 個合わせると元の正方形

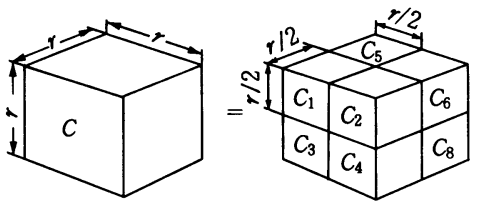

$1 / 2$ の立方体を $2^{3}$ 個合わせると元の立方体

図 2 直線, 正方形, 立方体の次元の求め方

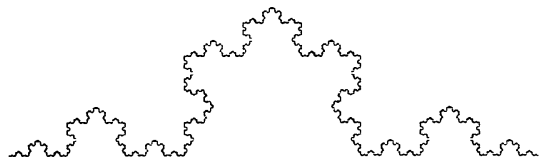

因 $3 \operatorname{Koch}$ 曲線 $(D=1.2618594 \cdots)$

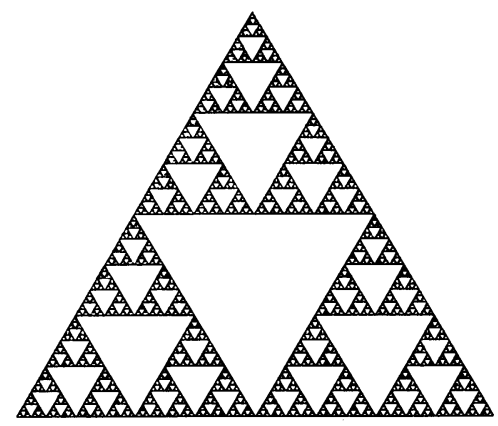

図 4 Sierpinskiの gasket $(D=1.5849626 \cdots)$

て得られる自己相似性のある図形である。前述の方法 でてのKoch 曲線の次元を求めてみよう。ての場合, 単位長さ $r$ を $1 / 3$ にすると単位図形の個数 $N$ は 4 倍に なる。したがってての図形の次元 $D$ は先ほどと同様に して次式の関係から求められる。

$$
4=3^{D}
$$

すると次元は $D=\log 4 / \log 3=1.2618594 \cdots$ と実数にな ってしまう2)。確かに図3を見るとてのKoch曲線は直 線と同じ 1 次元というには複雑に曲がりくねっている が，平面というほど前後左右に広がっているわけでは なく, 1 次元と 2 次元の中間の性質を持っていること が分かる。

図 4 にSierpinskiのgasket之呼ばれる自己相似図形 を示した。この図形の場合は長さを $1 / 2$ にすると単位 図形の数は 3 倍になるので, 次元 $D$ は $\log 3 / \log 2=$ $\left.1.5849626 \cdots{ }^{2}\right)$ となる。直感的にあ図 3 より図 4 の図形 の方が 2 次元の平面により近く，てのような図形の複 雑さの違いが実数值のフラクタル次元で定量的に表わ せるととが分かる。

\section{3. フラクタル次元と自然界への応用}

1970 年代に入って Mandelbrotが, このような特殊 な幾何学的図形に対するハウスドルフ次元の定義を, 雲, 山, 樹木, 川, 海岸線, 稲妻などの自然界に見ら れる複雑な形に拡張して使用し，てれをフラクタル次 元あるいは相似次元と名づけた ${ }^{3,4)}$ 。

これらの自然界に見られる大小様々な凹凸をすつ複 雑な形は，それまでその複雑さのために定量的な検討 がほとんどなされていなかった。しかしてれらの複雑 
な形す, その長さ, 周長, 表面積などは, 測定の基準 単位(測定)を小さくすれば, どんどん大きくなり, ま た, あるスケールの範囲内で, てれらの形はその一部 分を搪大すれば統計的に元と相似な構造が得られるなど, の性質，すなわち自己相似性があるてとが明らかとなり， てれらの構造をフラクタル次元を使って表す研究が進 められ始めた。すちろん自然界に見られる自己相似性 は, 先に述べたKoch曲線などの幾何学的図形のよう に0から無限大のスケールで完全に成立するのではな く，ある範囲で近似的に自己相似性が成り立つので, これを統計的自己相似性と呼ぶ。

一例として河川のフラクタル次元を求めた場合を示 す4)。図 5 に示すアマゾン川のフラクタル次元をスケ 一ル変換法 ${ }^{5)}$ で求める。乙れは図 6 のように対象の河 川を一辺の長さが $r$ の正方形で覆い, 河川が含まれる 正方形の数 $N(r)$ を求める。 $r$ を変化させて同様な操 作を絽り返しN $(r)$ を求める。

$$
N(r) \propto r^{-D}
$$

得られた $N(\boldsymbol{r})$ とを図 7 のうに両対数プロットし， 直線関係が得られれば, その直線の勾配に-1 を乗じ たものが求める河川のフラクタル次元となる。アマゾ

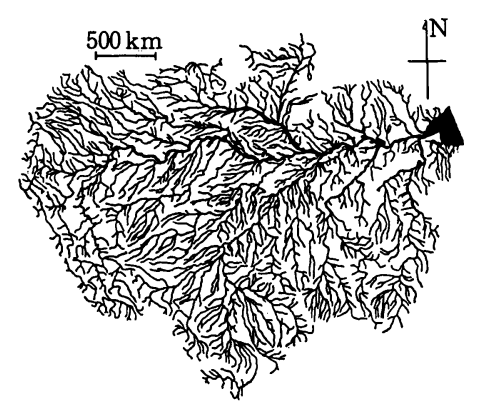

因 5 アマソัン川の形 $(D=1.85)^{4)}$

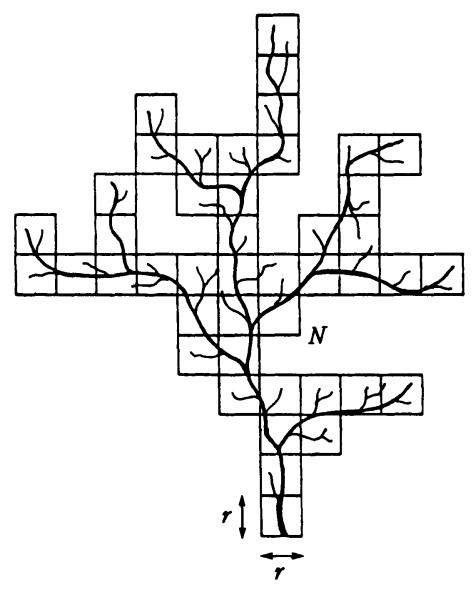

スケール変換法によるフラクタル次元測定原理 ${ }^{5)}$

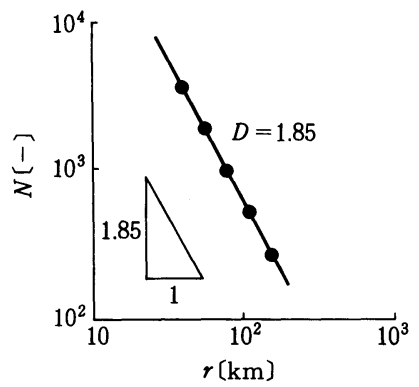

図 7 正方形辺長 $r$ 之河川を含む正方形数 $N(r)$ の関係 ${ }^{4)}$

ン川のフラクタル次元は図7 の直線の傾きから 1.85 と 大きな值を示した。同様な方法で砂漠の中を流れるナ イル川の次元を求めると 1.1 (乾期)から 1.4 (雨期)とな った。一般に降水量の少ない地域の河川のフラクタル 次元は 1 亿近く, 降水量の増加ととあに地表全体が水 に被われていくために次元が大きくなり平面の次元 2 に近づく"。

同様な方法で自然界に存在する種々の分岐構造を持 つあののフラクタル次元が求められている。たとえば, 人間の肺の気管は 2.17 次元, コウモリの翼の血管は 2.3 次元と 2 次元に近いのに対して, 人間の脳表面のしわ は 2.73 2.79 次元之 3 次元に近いのは興味深い。一方, 木や草の茎や枝は, 蔦の 1.28 次元からシャリントウ(バ ラ科の低木)の 1.79 次元までいろいろな值を取るが, 平 均 1.5 次元程度, 雷の稲妻は 1.7 次元程度である4)。

自然界に見られる複雑に入り組んだ境界線すフラク タル次元を用いて研究されている。たとえば, 縮尺の 違う地図から求めた海岸のフラクタル次元は，1（滑ら かな砂浜)から 1.3 (入り組んだリアス式海岸)の範囲に 入る ${ }^{5)}$ 。また, 気象衛星から撮影された雲の投影像の 輪郭は自己相似性を示し, そのフラクタル次元は雲の 種類にかかわらずほぼ 1.35 次元になることが明らかとな った ${ }^{4,5)}$ 。乙の値は水面に畦を落として作った墨絵(あ るいはコーヒーにミルクを落としたときに見られる模 様でも同様)の次元 1.3 に近いととから, 大気の大きな 流れと容器中の小さな流れとがよく似た性質を持ち, 乱流の普遍性がフラクタル次元から明らかになるので はないかという期待あ持たれている゙)。

てのように, フラクタル次元という新しい概念は数 学の分野にとどまらず, 物理学, 地学, 生物学, 気象 学, 流体力学などの幅広い分野で, これまでの幾何学 では取り扱えなかった自然界の複雑な形を定量化し, 自然現象の解明に用いられるようになってきている。 


\section{4. フラクタル次元の粉体工学への応用}

我々が対象とする粉体工学の分野であ，いろいろな 所でフラクタル次元が用いられるようになってきた。 それらのうち粒子の形状や粒子堆積構造の定量化にフ ラクタル次元を用いた例を中心に，フラクタル次元の 粉体工学への応用について説明する。

4.1 粒子投影像のフラクタル次元

粉粒体の粒子を走查電子顕微鏡や拡大投影器で写真 撮影し，乙の粒子投影像写真を基にデジタイザーを用 いて粒子の輪郭線上の X, Y座標をパソコンに入力す る。てのようにして得られた輪郭線を図8のように長 さ $r$ の直線で折れ線近似し，その本数 $N(r)$ を求める。 直線の長さ $r$ を短くすると本数 $N(r)$ は增加するが, そ の增加割合は輪郭線の凹凸が激しいほど大きい。乙れ は輪郭線の凹凸が激しいほど，rを小さくすると大き な場合には表れなかった小さな凹凸が折れ線近似に表 れて, 折れ線の本数 $N(r)$ が增加するためである。輪郭 線のフラクタル次元は, 図 10 のように $r$ と $N(r)$ を両 対数プロット(Richardsonプロット)して得られる直線 の傾きにー 1 を揞けて得られる4-8)。

$$
N(r) \propto r^{-D}
$$

なお，粒子投影像をテレビカメラなどで直接入力する 場合には，河川のフラクタル次元を求める際に用いた

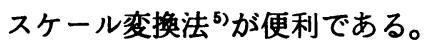

一例として, 炭酸カルシウム粒子投影像の輪郭線と それについてのRichardsonプロットを図 9,10に示し た。図 10 から最小自乗法で求めたフラクタル次元 $D$ は 炭酸カルシウムで 1.134 あったが, ガラスビーズでほぼ

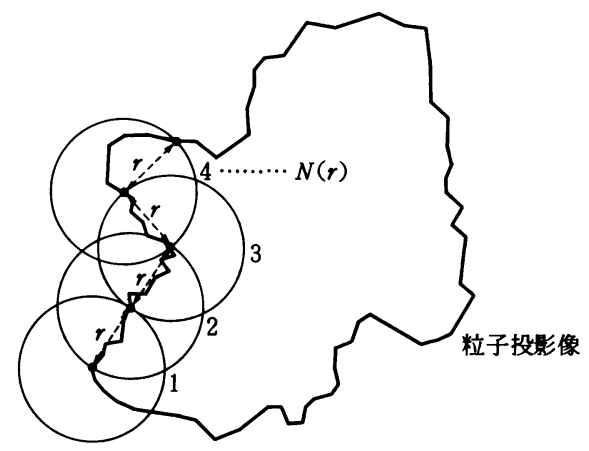

図 8 粒子投影像のフラクタル次元測定原理 ${ }^{6)}$

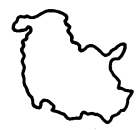

図 9 炭酸カルシウム粒子投影像の一例 ${ }^{6)}$

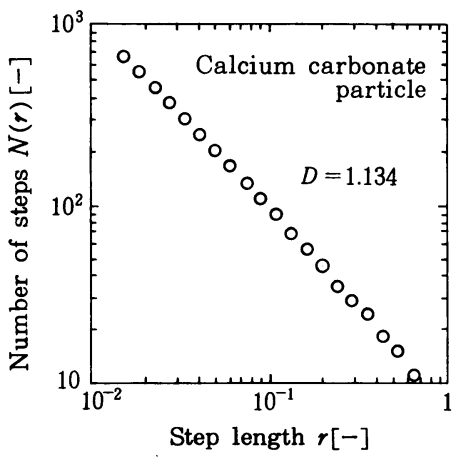

図 10 因9 粒子投影像についてのRichardsonプロット6)

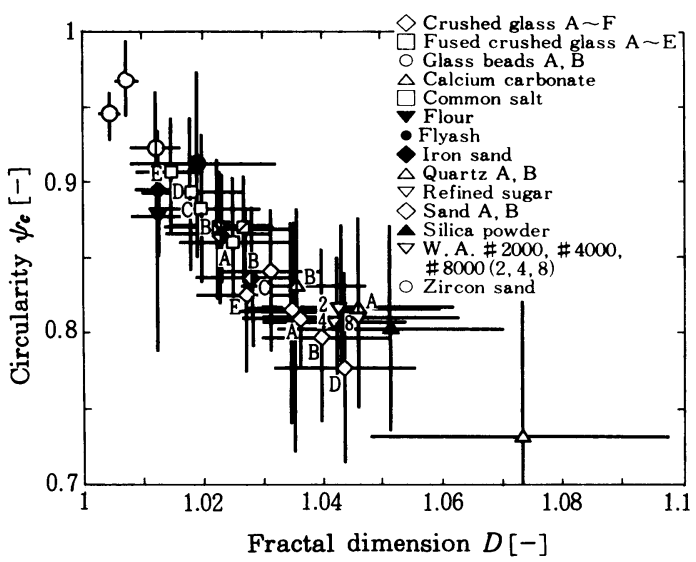

図 11 円形度 $\psi_{c}$ とフラクタル次元 Dとの関係 ${ }^{6)}$

1 となり, 表面の滑らかな粒子の投影像のフラクタル 次元は 1 亿近く，粒子表面の凹凸が激しくなるにつれ て大きくなり，2に近づくことが分かる。

これら以外にガラス破砕片, アルミナ, 塩, 小麦粉 など合計 28 種類の粉粒体粒子の写真を撮り,それぞれ について約 100 個の投影像輪郭線のフラクタル次元を 求め, その平均值と従来用いられている代表的な形状 指数である円形度 $\psi_{\mathrm{c}}(=$ 粒子投影面積之同じ面積の円 の周長/粒子投影像の輪郭の長さ)とを比較した。その 結果, 図 11 に示すように, フラクタル次元 $D$ が増加す るほど円形度 $\psi_{\mathrm{c}}$ が直線的に隇少するという良い相関関 係が得られた ${ }^{6)}$ 。したがって粒子投影像のフラクタル 次元は，その表現方法が従来の形状指数と異なるにし てあ，円形度と同様に粒子表面の凹凸状態を表わすす のがあるととが明かとなった。

\section{2 分子吸着を用いた粒子表面のフラクタル次元} 測定

このように粒子表面のフラクタル次元は, 円形度と 一定の関係を持ち，粒子形状を定量的に表しているて とが確かめられたので, 粒子投影像輪郭線の折れ線近 


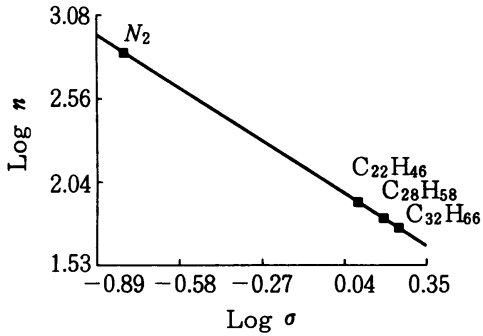

図 12 分子占有面積 $\sigma\left(\mathrm{nm}^{2}\right)$ と吸着分子モデル数 $n[\mu \mathrm{mol} / \mathrm{g}]^{10)}$

似の場合に用いた長さの異なる直線の代わりに分子径 の異なる分子を用い，乙れを粒子表面に吸着すること により粒子表面の立体的な形状を表現できる。

吸着した 1 分子が粒子表面上で占める占有面積を $\sigma$ とすれば, これは分子径 $r$ の 2 乗に比例するから式(6) より次式が成立する ${ }^{9,10)}$ 。

$n \propto \sigma^{-D / 2}$

こてで $n$ は粒子単位質量あたりに単分子層吸着した分 子数あるいはモル数である。分子径あるいは分子吸着 面積 $\sigma$ 異なる数種類のガスを用い，それぞれが粒子 表面に単分子層を形成するのに必要な試料粒子単位質 量あたりの分子数あるいはモル数 $n$ をガス吸着実験に よって求め, 式(6)の関係から粒子表面のフラクタル次 元 $D$ を求めた例を図 12 亿示した。

図 12 亿示したAvnirらの実験結果 ${ }^{100}$ は, 実験試料に グラファイト, 吸着媒は窒素, $\mathrm{C}_{22} \mathrm{H}_{46}, \mathrm{C}_{28} \mathrm{H}_{58}, \mathrm{C}_{32} \mathrm{H}_{66}$ の 4 種類を用いたもので, てれより求められた表面の フラクタル次元は 2.07 と滑らかな表面の次元 2 に近い。 それに対してシリカゲルや活性炭などの多孔質試料表 面のフラクタル次元は 3 に近いととが報告され，表面 の立体的な凹凸状態がフラクタル次元で表わせること がわかる ${ }^{11)}$ 。測定精度などにまだ問題は残るが，分子 吸着を用いた微粒子のフラクタル次元測定は, 比表面 積の大きな微粒子ほど測定精度が上がるので, 電子顕 微鏡による形状測定が難しい超微粒子表面の凹凸状態 の定量化などに今後利用できる可能性があると期待さ れる。

\section{3 均一径球形粒子ランダム充垻首のフラクタル 次元}

粒子層内の粒子の詰まり方(充填構造)の连いを表わ すのに, 乙れまでは空間率 $\varepsilon$ や平均配位数(粒子 1 個 あたりの接触点数) $\bar{N}_{\mathrm{c}}$ などが用いられてきたが，てれ らでは充分表わせない充填構造の違いあ存在する ${ }^{12)}$ 。 そこでフラクタル次元を用いて他の方法では表わせな かった充填構造の違いを表現できた例 ${ }^{13}$ について説明 する。

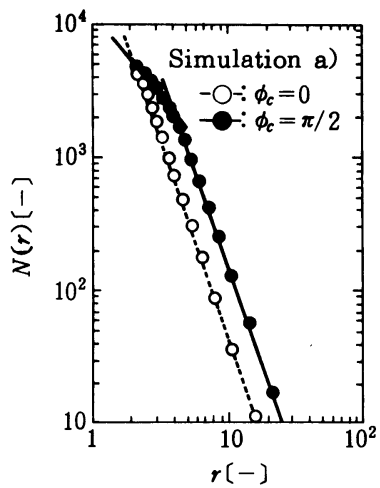

図 13 立方体辺長 $r$ 之粒子中心を含む立方体数 $N(r)$ の関 係 ${ }^{13)}$

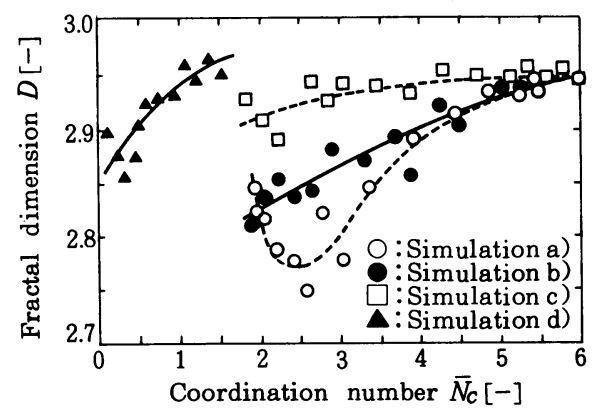

図 14 配位数 $\bar{N}_{c}$ とフラクタル次元 $D$ の関係 ${ }^{13)}$

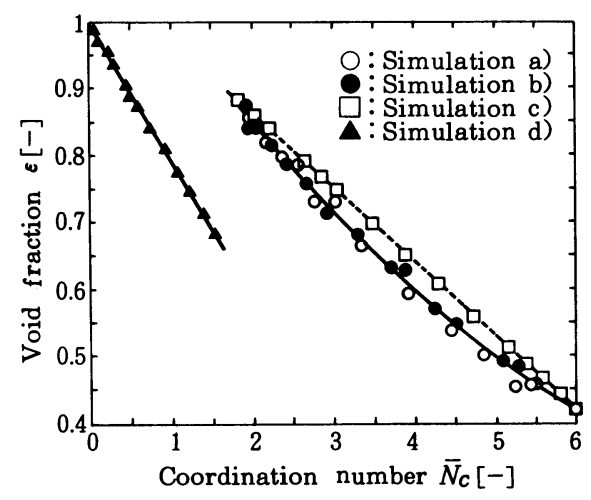

図 15 空間率 $\epsilon$ 之跽位数 $\bar{N}_{c}$ の夙係 ${ }^{13)}$

電算機シミュレーションで作った粒子層について河 川の場合と同様にスケール变換法でフラクタル次元を 求めた。1 辺の長さが $r$ の立方体で粒子層を分割し, 粒子の中心が含まれる立方体の数 $N(r)$ とする。 $r$ を変 化させ, $r$ と $N(r)$ を両対数プロットした例を図 13 に 示した。この直線の傾きにー1を掛けて粒子層のフラ クタル次元 $D$ を求めた。

図 14 に 4 種類の異なるプログラムで作成した粒子 層について求めたフラクタル次元 $D$ と平均配位数 $\bar{N}_{\mathrm{c}}$ 
の関係を示した。乙れらのうち 3 種類のプログラムに よる充填構造の連いが, 図 15 の配位数 $\bar{N}_{\mathrm{c}}$ と空間率 $\varepsilon$ の関係では明瞭ではなかったが，図14の配位数とフラ クタル次元の関係からは明らかに区別できた。てれらの 結果より，てれまでの方法では表せない粒子充塓層の 粒子配列構造の違いがフラクタル次元によって表せる ことが分かった。

\section{4 粉体工学に対するフラクタル次元のその他の 応用例}

てのようにフラクタル次元は, 粒子充塓層内の粒子 配列状態を定量化できるばかりでなく, 同様な方法で 微小な粒子の凝集物の構造, たとえば疑集フロック形 状 ${ }^{14)}$, 図 16 のような 2 次元拡散律速ランダムウォーク

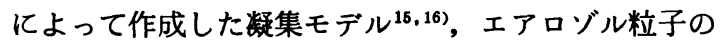
凝集構造 ${ }^{17}$, さらには集蝔に関係して 1 本の織維上へ の粒子の付着状態 ${ }^{18)}$ な゙を定量的に表現するのにあ用 いるととができる。

これらの他, 粉砕産物のフラクタル次元より粉砕機 構 ${ }^{19)}$ や粉砕エネルギー則 ${ }^{20)}$ を検討する研究など粉砕関 係であ使われはじめており, 粉粒体工学の分野でフラ クタル次元は幅広く用いられるようになってきている。

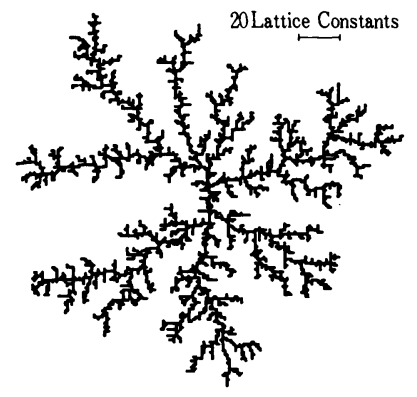

图 162 次元拡散律速でつくられたランダム数集体 ${ }^{15)}$ $(D=1.55)$

\section{5. おわりに}

工学全体に目を広げれば,さらに広い分野でフラク タル次元が用いられている。たとえば乱流構造の表現 にフラクタル次元が用いられ，境界層流の境界面は $2.38 \sim 2.40$ 次元, 軸対称噴流では 2.32 2.33 次元にな ると報告されている21)。また強磁性イジングモデルで の二次相転移をフラクタル次元を用いて検討した研

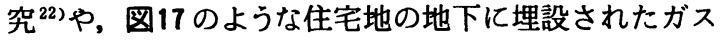
管網をフラクタル次元で表わし，てれが地震により切 断された場合どのような順番で復旧してゆけばよいか を,フラクタル次元の值を用いて検討する試みなども 行なわれている23)。

てれらのようにフラクタル次元は誕生してまだ10年 余りの新しい概念であるが, 理学, 工学, 医学を含め たいろいろな分野で, 複雑な形や構造を簡単に定量化 するために広く使われ始めている。てれまでの方法で うまく表現できなかった何かがフラクタル次元を用い て定量的に, しかあ簡単に表せる例あ多く, 今後粉体 工学のいろいろな分野でフラクタル次元が幅広く応用 されることが期待される。

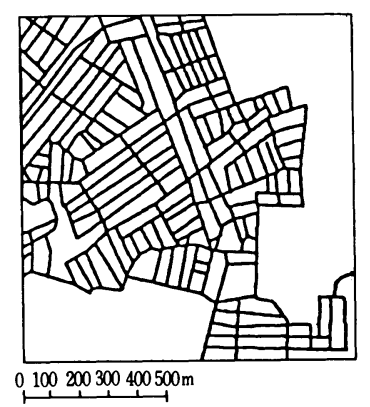

図 17 住宅地のガス配管網 $(D=1.79)^{22)}$

\section{使 用 記 号}
$D:$ フラクタル次元
[-] $\varepsilon$ : 空間率
$N$ : 単位図形の数
〔-] $\sigma:$ 分子占有面積
$\left[\mathrm{nm}^{2}\right]$
$\bar{N}_{\mathrm{c}}$ : 平均配位数
$[$ 一]
$\phi_{c}$ : 粒子充填シミュレーションの粒子間摩擦角
$n:$ 粉体単位質量あたりの吸着分子数あるいはモル数

$$
\left[\mathrm{g}^{-1} \text { または } \mu \mathrm{mol} / \mathrm{g}\right] \quad \psi_{\mathrm{c}} \text { ：円形度 }
$$
[rad]
$r$ : 代表長さ
〔kmまたは一〕

\section{引用 文 献}

1) 山口昌哉 : “カオスとフラクタル”, p. 183, 講談社 (1986)
2 ) 木上淳 : 数理科学, No. 302,18 (1988)

3) Mandelbrot, B. B., 広中平祐監訳 : “フラクタル幾何 
学”, p. 84〜279, 日経サイエンス社(1984)

4 ) 高安秀樹: “フラクタル”, p. 32〜69, 朝倉書店 (1986)

5 ）松下貢ほか: “かたちの科学”, p. 90〜 110, 朝倉書店 (1987)

6 ) 鈴木道隆, 六車嘉貢, 廣田満昭, 大島敏男 : 粉体工学 会誌, 25, 287 (1988)

7) Schwarz, H. and H. E. Exner : Powder Technol., 27, 207 (1980)

8 ) Clark, N. N, : Powder Technol., 46, 45 (1986)

9 ) 六車嘉貢, 廣田満昭, 鈴木道隆, 大島敏男 : 昭和63年 度粉体工学会春期研究発表会講演要旨集, p. 68 (1988)

10) Avnir, D. and D. Farin : J. Chem. Phys., 79, 3566 (1983)

11) Avnir, D. : "The Fractal Approach to Heterogeneous Chemistry", p. 273 293, John Wiley \& Sons (1989)
12）鈴木道隆, 大島敏男 : 粉体工学会誌, 25, 204 (1988)

13）鈴木道隆, 大島敏男 : 粉体工学会誌, 26, 250 (1989)

14）荒谷敏朗, 藤井達也, 森川利哉, 宮南啓 : 化学工学論 文集, 14, 395 (1988)

15) Witten, T. A. and L. M. Sander : Physical Review Letters, 47, 1400 (1981)

16）早川尚男 : 数理科学, No. 291, 42 (1987)

17）東野達, 高橋幹二：エアロゾル研究, 2, 117 (1987)

18）金岡千嘉男, 平木外二：化学工学協会第 21 回秋季大会 講演要旨集, p. 478 (1988)

19）遠藤茂寿, 空閑良寿, 武内一夫 : 化学工学協会第 53 年 会講演要旨集, p. 111 (1988)

20）鈴木徹, 矢野俊正 : 粉体工学会誌, 26, 99 (1989)

21) 山田道夫 : 数理科学, No. 291, 30 (1987)

22) 伊藤伸泰 : 数理科学, No. 301, 62 (1988)

23）佐竹正雄, 中川昌美 : 形の科学会報, 13, 7,（1988）

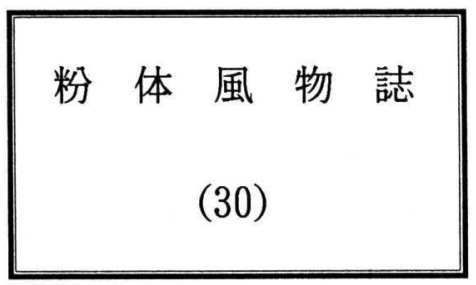

\section{サンホセ修道院の鞍石}

1492年コロンブスのアメリカ発見の航海より数えて 1992年は500年になるが，米国では1992年には国を挙げ てのお祭りをする由である。それはさて置き，海外志向 のスペインは中南米および北米にも植民地化政策を進め て行った。また植民地化の先鋒をつとめたのが宗教であ り，17世紀頃になると各地に修道院が建てられ現地人 (インディアン) の教化にあたった。テキサス州サンア ントニオの郊外にあるサンホセの修道院もその一つで, 写真の僧院を中心にインディアンの住む住居が城砦の壁 に沿ってあり, 中の広場では様々な教化が行われた由で ある。もう一つの写真はインディアンの使っていた鞍石 で，広場にあるパン焼窟でパンを焼いていたという。

(奥田 聡)

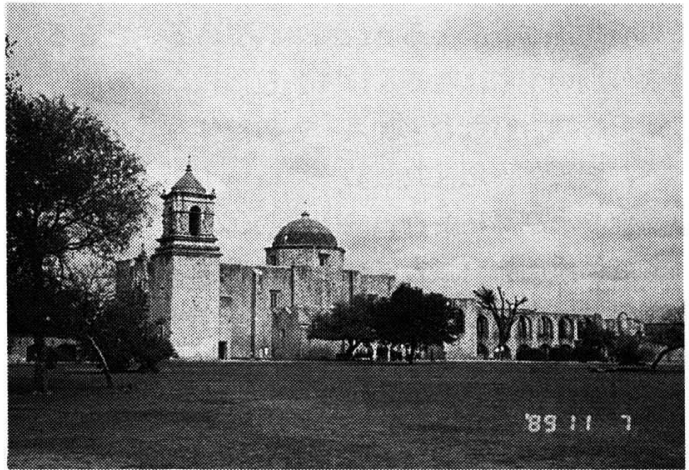

（San Jose 修道院）

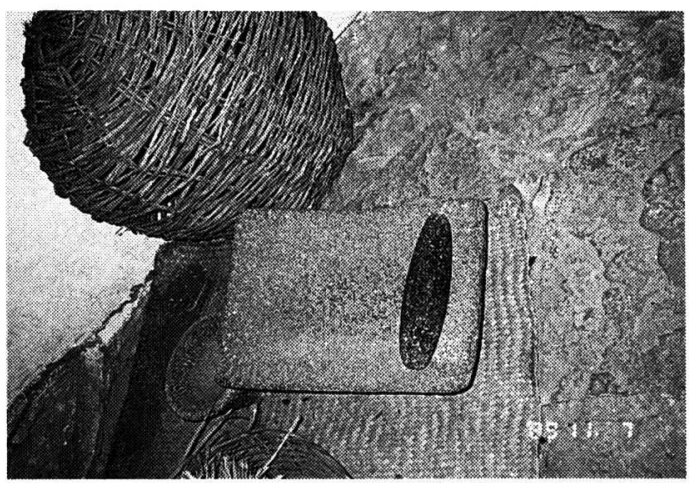

(鞍
石） 